\title{
Bir halk sağlığı sorunu: çocuk sağlığı izleminde D vitamini
}

\author{
A public health problem: vitamin D status in child health follow up
}

\author{
Gökce Celep, Zeynep Hülya Durmaz
}

Gönderilme tarihi:16.06.2020

Kabul tarihi:28.08.2020

Özet

Amaç: D vitamini direk güneş ışığı altında deride sentezlenen bir hormondur. Eksikliği ve yetersizliği çocukları etkileyen evrensel bir sorundur. Sağlıklı büyüme ve gelişme için gereklidir. Birçok sistemi etkileyen düzenleyici rolü vardır. Eksiklik eşik değerinin belirlenmesinde parathormon ile olan ilişkisi önemlidir. Bu yazıda amaç, ülkemiz için yakın geçmişte belirlenen eşik değerler göz önüne alınarak hastanemize başvuran çocuklardaki D vitamini eksikliği sıklığının belirlenmesidir.

Gereç ve yöntem: Çalışmaya katılan ve bilinen kronik sağlık sorunu olmayan çocuklara ait kayıtlar hastane bilgi sistemi üzerinden retrospektif olarak tarandı. Yaş, cinsiyet, parathormon (PTH), kalsiyum (Ca+2), fosfor (P), alkalen fosfataz (ALP), 25(OH)D düzeyleri kayıt altına alındı. Yaş grupları, cinsiyet, mevsimler dikkate alınarak istatistik paket programıla analiz edilip sunuldu.

Bulgular: Çalışmaya yaşları 1-17 arasında değişen 229'u (\%45,6) erkek, 273'ü (\%54,4) kız, 502 sağlıklı çocuk katıldı. Uzman kuruluşlarının önerileri dikkate alındığında D vitamini eksikliği (25 (OH)D <12 ng/ml) oranı \%26,7 $(n=134)$ idi. Katılımcıların \%47,2'sinde "yeterlilik" söz konusu idi. Eksiklik sıklığının yaşla artması, kızlarda ve kış mevsiminde daha sık olması istatistiksel olarak anlamlı idi (sırasıyla: $p<0,0001 ; p=0,0031 ; p<0,0001$ ).

Sonuç: İlimiz Kuzey Yarımküre'nin ılıman iklim kuşağında yer almasına rağmen çalışma grubunun%50'sinden fazlasında D vitamini eksikliği veya yetersizliği mevcuttur. Güneş maruziyetinin arttırılması, destek tedavilerinin uygulanması ile bu sorunun çözülmesinde gereklidir. Yaşamın ilk bir yılında uygulanan D vitamini destek programı bu yaş grubunda başarılı sonuçlar sağlamıştır. Benzer bir uygulamanın diğer yaş grupları için de yararlı olacağı düşünülmektedir.

Anahtar kelimeler: Çocuk sağlığı, D vitamini, eksiklik, yetersizlik.

Celep G, Durmaz ZH. Bir halk sağlığı sorunu: çocuk sağlığı izleminde D vitamini. Pam Tıp Derg 2021;14:63-70.

\begin{abstract}
Purpose: Vitamin D is a hormone, synthesized in the skin under the direct sunlight. Deficiency of vitamin $D$ is a significant global problem in children. It is necessary for well growing up and development. It acts as a regulator in many systems. Its relationship with parathormone is important to detect the cut off value of deficiency. The aim of this article is to determine the prevalence of vitamin $D$ deficiency in children in our province by considering the recently established threshold values for our country.

Materials and methods: The records of children who were known to have no chronic health problem, were retrospectively reviewed through the hospital information system. Age, sex, parathormone (PTH), calcium $(\mathrm{Ca}+2)$, phosphorus $(\mathrm{P})$, alkaline phosphatase $(A L P), 25(\mathrm{OH}) \mathrm{D}$ levels were recorded. The data were analyzed and presented with statistical package program considering age, gender and seasons.

Results: Five hundred and two children, 229 (45.6\%) boys and $273(54.4 \%)$ girls, aged 1 to 17 years enrolled in the study. Considering recommendations of authorities, the rate of vitamin D deficiency $(25(\mathrm{OH}) \mathrm{D}<12 \mathrm{ng} / \mathrm{ml})$ was $26.7 \%$ ( $n=134)$. Sufficiency was detected in the $47.2 \%$ of the participants. The rate of deficiency was higher in older groups, in females and in winter which were all statistically significant $(p<0,0001 ; p=0.0031 ; p<0,0001$, respectively).

Conclusion: Although our city is located in the temperate zone of the Northern Hemisphere, more than $50 \%$ of the study population had vitamin D deficiency or insufficiency. Supplementation treatments and increasing sun exposure are necessary to solve this problem. The vitamin supplementation in the first year of life, has provided successful outcomes in this age group. A similar practice is thought to be beneficial for other age groups.
\end{abstract}

Key words: Child health, vitamin D, deficiency, insufficiency.

Celep G, Durmaz ZH. A public health problem: vitamin D status in child health follow up. Pam Med J 2021;14:6370.

Gökce Celep, Dr. Öğr. Üye. Amasya Üniversitesi Tıp Fakültesi, Sabuncuoğlu Şerefeddin Eğitim ve Araştırma Hastanesi, Çocuk Sağlığı ve Hastalıkları Anabilim Dalı, Amasya, Türkiye, e-posta: gokce4celep@yahoo.com (orcid.org/0000-0001-6250-5096) (Sorumlu Yazar)

Zeynep Hülya Durmaz, Uzm. Dr. Amasya Üniversitesi Tıp Fakültesi, Sabuncuoğlu Şerefeddin Eğitim ve Araştırma Hastanesi, Biyokimya Bölümü, Amasya, Türkiye, e-posta: aakdenizhulyaa2141@gmail.com (orcid.org/0000-0002-3260-0030) 


\section{Giriş}

D Vitamini deride sentezlenen bir prohormondur, 7- dehidrokolesterolün 290-315 $\mathrm{nm}$ dalga boyundaki ultraviyole $\mathrm{B}$ (UVB) ışınları altında gerçekleşen izomerizasyonu sonucu oluşur. Deride sentezlenen formu kolekalsiferol (vitamin D3), besinlerle alınan formu ergokalsiferol (vitamin D2) olmak üzere iki formu vardır. İnsan vücudundaki D vitaminin \%90'dan fazlası deride sentezlenir. Uzun yıllardır kemik metabolizması ve sağlığına etkileri bilinmektedir. Son yıllarda sinir, kalp, gastrointestinal sistem, bağışıklık sistemi üzerindeki etkilerinin fark edilmesiyle gündemdedir [1-3].

D vitamini ağırlıklı olarak karaciğer ve böbrekteki hidroksilasyon işlemleri ile aktif formu olan 1,25 $(\mathrm{OH}) 2$; "kalsitriol"e dönüşür. Birincil metaboliti $25(\mathrm{OH}) \mathrm{D}$ ise $\mathrm{D}$ vitamini durumunu değerlendirmede en güvenilir ve sık kullanılan laboratuvar tetkikidir. Serum yarılanma ömrü yaklaşık olarak üç haftadır, bu sayede akut değişikliklerden etkilenmez [1]. Vücuttaki kalsiyum $\left(\mathrm{Ca}^{+2}\right)$ fosfor $(\mathrm{P})$, parathormon $(\mathrm{PTH})$ ve $D$ vitamini dengesi birbiriyle ilişkili hassas mekanizmalarla sağlanır [1-3]. Parathormon ve $D$ vitamini arasında ters bir ilişki söz konusudur. Her ikisi de kemik metabolizmasının ana aktörleri olarak $\mathrm{Ca}^{+2}$ ve $\mathrm{P}$ dengesi ve kemik sağlığından sorumludur [1, 2]. D vitamini eksikliğinde serum $\mathrm{Ca}^{+2}$ seviyesi düşer, PTH salınımı artarak kemiklerden kana $\mathrm{Ca}^{+2}$ geçişi sağlanır. Kemik mineralizasyonunu bozan bu durumda PTH salınımını tetikleyen en düşük $D$ vitamini düzeyi "D vitamini eksikliği" olarak tanımlanır [4].

Türkiye kuzey yarımkürenin ılıman iklim kuşağında yer alan güneşli bir ülke olmasına karşın D vitamini eksikliği (VDE) sık görülen bir halk sağlığı sorunudur. İlk bir yaşta aile sağlığı merkezlerinden ücretsiz sağlanan D vitamini damlalarıyla gerçekleşen destek programı maalesef hayatın ikinci yılından sonra etkinliğini kaybetmektedir [5, 6]. Tüm dünyada olduğu gibi çocukların oyun alışkanlıklarının değişmesi, açık havada geçirilen zamanın azalması, güneş koruyucu kremlerin kullanımı, yeterli güneş ışığına maruziyeti azaltan giyiniş özellikleri, yetersiz fiziksel aktivite, kısıtlı deniz ve mandıra ürünlerinin tüketimi ülkemizde VDE sıklığının önemli nedenleri arasındadır [1]. Anne sütündeki $D$ vitamini içeriği yetersizdir [7]. Bazı gelişmiş ülkelerde süt ürünleri, meyve suları gibi birtakım besinlerin zenginleştirilmesi söz konusudur; ancak bu kaynakların etkin olması için yeterli miktarda bu besinlerin tüketilmesi gereklidir. Bu koşul ve etkin güneş ışığından yararlanma sağlanamıyorsa destek tedavisinin olmaması eksiklikle sonuçlanır [1].

Son yıllarda kemik dışı etkileri fark edilince popüler hale gelen $D$ vitamini ile ilgili pek çok araştırma yapılmış, ancak "eksiklik" tanımı için net bir görüş birliği oluşmamıştır. Amerikan Pediatri Akademisi (APA) kılavuzlarına göre 25 $(\mathrm{OH})$ D3 düzeyleri $<5 \mathrm{ng} / \mathrm{mL}$ ise "ağır eksiklik", $<15 \mathrm{ng} / \mathrm{mL}$ ise "eksiklik", $15-20 \mathrm{ng} / \mathrm{mL}$ ise "yetersizlik", 20-100 ng/mL ise "yeterli", 101$150 \mathrm{ng} / \mathrm{mL}$ ise "fazlalık", $>150 \mathrm{ng} / \mathrm{mL}$ ise "toksik düzey" olarak tanımlanmaktadır [8]. Uluslararası Endokrin Derneği'nin 2015 yılındaki raporunda eksiklik $<30 \mathrm{nmol} / \mathrm{mL} \quad(<12 \mathrm{ng} / \mathrm{mL})$, yetersizlik $30-50 \mathrm{nmol} / \mathrm{mL}(12-20 \mathrm{ng} / \mathrm{mL})$, yeterlilik $>50$ $\mathrm{nmol} / \mathrm{mL}(>20 \mathrm{ng} / \mathrm{mL})$ olarak tanımlanmaktadır. Sınır değer olan $30 \mathrm{nmol} / \mathrm{mL}=12 \mathrm{ng} / \mathrm{mL}$ "D vitamini eksikliğine bağı nutrisyonel riketsi önlemeyi sağlayan" en düşük değer olarak değerlendirilmektedir $(1 \mathrm{ng} / \mathrm{mL}=2,5 \mathrm{nmol} / \mathrm{L})$ [9]. T.C. Sağıı Bakanlığı Bilimsel Danışma Kurulu'nun önerisi de bu değerlerin göz önünde bulundurulması gerektiği yönündedir [10]. Kore'den 2017 yılında yayınlanan bir çalışmada ise sınır değer $18 \mathrm{ng} / \mathrm{mL}$ olarak tanımlanmıştır, bu değer çocuklarda PTH değerinin artışa geçmediği zirve değerdir [11]. Ancak ABD'de yapılan bir çalışmada sağlıklı çocukları değerlendiren araştırmacılar büyümesi devam eden bireylerde 25(OH)D için bir eşik değer belirlenemeyeceğini, olguların PTH ile birlikte değerlendirilerek PTH'da artış varsa eksiklik tanısının bireysel olarak konması gerektiğini vurgulamışlardır [12].

Bu yazıda amaç Orta Karadeniz'de küçük bir ildeki referans hastaneye başvuran çocuklarda ölçülen serum $25(\mathrm{OH})$ D düzeyi ve $\mathrm{PTH}, \mathrm{Ca}^{+2}$, $P, A L P$ düzeylerinin ilişkisini saptamak ve bu popülasyondaki D vitamini eksikliği sıkığını ortaya koymaktır.

\section{Gereç ve yöntem}

Bu çalışma bir üçüncü basamak sağlık kuruluşunun çocuk sağlığı ve hastalıkları polikliniklerinde gerçekleştirilmiştir. Çalışmanın yapıldığı yerleşim yeri $36^{\circ} 57^{\prime} 06^{\prime \prime}-36^{\circ} 31^{\prime}$ $53^{\prime \prime}$ doğu meridyenleri, $41^{\circ} 04^{\prime} 54^{\prime \prime}-40^{\circ} 16^{\prime}$ $16^{\prime \prime}$ kuzey paralelleri arasında yer alan, $411 \mathrm{~m}$ rakımlı küçük bir ildir. Çalışmanın yapıldığı 
zaman diliminde ortalama global solar radyasyon 20,05-23,71 $\mathrm{MJ} / \mathrm{m}^{2}$, güneş alma süresi 6,8-11 saat/gün olarak bildirilmiştir [1315]. Polikliniklere ayaktan başvuran 1-17 yaş arası 32718 çocuk arasından $25(\mathrm{OH}) \mathrm{D} 3, \mathrm{Ca}^{+2}$, P, ALP, PTH istemi yapılmış 1873 çocuğun verileri hastane kayıtları üzerinden incelenmiştir. Her hangi bir nedenle 3 aydan uzun süren ilaç veya diyet tedavisi alan çocuklar, kronik hastalıkları olanlar (astım, diyabet, epilepsi, serebral palsi, malabsorbsiyon sendromları, hipotiroidi, konjenital kalp hastalıkları, kalsiyum ve $D$ vitamini metabolizması ile ilgili hastalığı olduğu bilinenler) Türk çocuklarının yaş ve cinsiyete dayalı persantil eğrilerine göre vücut ağırlığı ve boyları 3. persentilin altında, 97. persentilin üzerinde olan çocuklar, vücut kitle indeksi (VKí) (ağırlık (kg) / boy $(\mathrm{m})^{2}$ ) formülüne göre \%95'in üzerinde olan 1371 çocuk çalışma dışı bırakıımıştır. Buna göre 01 Ocak 2016-31 Aralık 2017 tarihleri arasında başvuran, serum $25(\mathrm{OH}) \mathrm{D} 3, \mathrm{Ca}^{+2}, \mathrm{P}, \mathrm{ALP}$, PTH değerleri bakılan ve yukarda belirtilen kriterleri karşılayan 502 çocuğun değerleri incelenmiştir. Çocuk polikliniklerinin işleyişi gereği tüm çocukların ağırlık ve boyları fizik inceleme öncesi kalibrasyonu yapılmış terazi ve boy ölçer ile ölçülmüştür. Yine hastane kuralları gereğince fizik muayene sonrasında venöz kan örnekleri sabah 8:30-12:00 saatleri arasında alınarak hastanenin biyokimya laboratuvarına gönderilmiştir. Tüm kan örnekleri biyokimya uzmanı olan araştırmacının denetiminde aynı cihaz ve teknikle çalışılmıştır. Serum $25(\mathrm{OH})$ $\mathrm{D}$ düzeyleri, tüm popülasyon ve zaman dilimleri için referans aralığının 20-100 ng/mL olarak tanımlandığı elektrokemiluminesan yöntemiyle (Siemens Advia Centaur XP®, Erlangen Almanya) ile çalışılmıştır. Soğukzincirkurallarına uyularak laboratuvara gönderilen PTH, elektrokemiluminesan yöntemi ile (Siemens Advia Centaur XP®, Erlangen Almanya), ALP kinetik testle, $\mathrm{Ca}^{+2}$ ve $\mathrm{P}$ düzeyleri fotometrik yöntemle ile (Beckman Coulter AU 5800®, Brea California, ABD) ölçülmüştür. Sonuçların değerlendirilmesi için hastalar yaşlarına göre 1 . grup:1-8 yaş ( $n=355) ; 2$. grup: 9-17 yaş $(n=147)$ olmak üzere iki gruba ayrılmıştır. Sınırlı sayıda hastadan istenen el bilek grafileri yine sistem üzerinden incelenmiştir $(n=12)$ ve yüksek doz $D$ vitamini reçete edilen hastalar $(n=10)$ kayıt edilmiştir. $25(\mathrm{OH}) \mathrm{D}$ düzeyleri Sağlık Bakanlığı önerileri doğrultusunda tanımlanmıştır: Eksiklik:
$25(\mathrm{OH}) \mathrm{D}<12 \mathrm{ng} / \mathrm{mL}$; yetersizlik: 12-20ng/mL; yeterlilik: 20-100 ng/mL; intoksikasyon: >100ng/ $\mathrm{mL}$ olması ve buna hiperkalseminin eşlik etmesi [10].

\section{İstatistiksel analiz}

Analiz için "SPSS 15.0 for Windows" (SPSS, Inc., Chicago, IL, USA) bilgisayar paket program kullanılmıştır. Veriler tanımlayıcı istatistikler yardımıyla sıklık, ortalama, standart sapma, ortanca, en düşük ve en yüksek değerler olarak değerlendirilmiştir. Değişkenlerin normal dağılıma uyup uymadığını araştırmak için görsel (histogram) ve analitik yöntemler kullanılmıştır (Kolmogorov Simirnov testi). Değişkenlerin birbiriyle ilişkisi normal dağılıma uyanlar için student $\mathrm{t}$ testi, uymayanlar için Mann Whitney U testiyle; çoklu karşılaştırmalarda ise ANOVA ve Kruskall Wallis testleri ile (ikili karşılaştırmalar Mann Whitney $U$ testi ve Bonferroni düzeltmesi kullanılarak) yapılmıştır. Korelasyon değerlendirmesinde Spearman ve Pearson testleri kullanılmıştır.

$\mathrm{Bu}$ araştırma, Helsinki Bildirgesi ilkeleri dikkate alınarak hazırlanmış ve sunulmuştur. Çalışma için Amasya Üniversitesi'nin Girişimsel Olmayan Klinik Araştırmalar Etik Kurulu'ndan etik onay alınmıştır.

\section{Bulgular}

Çalışmaya yaşları 1-17 arasında değişen 502 çocuk katılmıştır (ortanca: 5; çeyrekler arası uzaklık (ÇAU): 8 yıl). Olguların \%45,6'sı $(n=229)$ erkek, \%54,4'ü $(n=273)$ kızdır. Kan örneklerinin 105'i $(\% 20,9)$ ilkbaharda, 101'i $(\% 20,61)$ kışın, 150'si $(\% 29,9)$ yazın 146'sı $(\% 29,1)$ sonbaharda alınmıştı. Tüm çalışma grubu göz önüne alındığında ortanca $25(\mathrm{OH})$ düzeyi 19,49 ng/dL $(4,2-89,4 ; \quad$ ÇAU:16,23) ortanca PTH düzeyi 38,75 pg/mL(11,1-146; ÇAU: 23,93), ortalama $\mathrm{Ca}^{+2}$ düzeyi $9,66 \pm 0,40$ $\mathrm{mg} / \mathrm{dL}$, ortalama $\mathrm{P}$ düzeyi $4,9 \pm 0,7$; ortalama ALP düzeyi 208,0 $\pm 86,7 \mathrm{IU} / \mathrm{mL}$ olarak saptanmıştır. Endokrin Derneği'nin 2015 yılındaki bildirisi ve buna paralel T.C. Sağlık Bakanlığı önerileri dikkate alındığında D vitamini eksikliği (25 $(\mathrm{OH}) \mathrm{D}<12 \mathrm{ng} / \mathrm{mL})$ oranı \%26,7'dir ( $\mathrm{n}=134)$. Katılımcıların \%26,2'inde $(n=131)$ yetersizlik (25 $(\mathrm{OH}) D$ düzeyi $12-20 \mathrm{ng} / \mathrm{mL}$ ) saptanmıştır. İki yüz otuz yedi katılımcıda $(\% 47,2)$ ise "yeterlilik" (25 $(\mathrm{OH}) D$ düzeyi: 20-100 ng/mL) mevcuttur. Hiçbir hastada intoksikasyon yoktur. Olguların 50 
(\%10) tanesinde PTH düzeyi yüksek (PTH>65 $\mathrm{pg} / \mathrm{mL})$, hipokalsemi $\left(\mathrm{Ca}^{+2}<8 \mathrm{mg} / \mathrm{dL}\right)$ ise sadece bir olguda saptanmıştır.

Çalışmaya dahil edilen 229 erkek katılımcının ortanca yaşı dörttür (1-17; ÇAU:8) Ortanca $25(\mathrm{OH}) \mathrm{D}$ ve PTH düzeyleri sırasıyla $21,75 \mathrm{ng} / \mathrm{mL}$ (ÇAU:16,64) ve $34,50 \mathrm{pg} / \mathrm{mL}$ (ÇAU:26,60) olarak saptanmıştır. Kızların yaş ortancası altıdır (ÇAU:8). $25(\mathrm{OH}) \mathrm{D}$ düzeyi ortancası 18,30 ng/mL (ÇAU:14,65); PTH ortancası ise 41,05 (ÇAU:22,53) $\mathrm{pg} / \mathrm{mL}$ olarak hesaplanmıştır. Kızların \%30,8'inde ( $n=84)$, erkeklerin \%21,8'inde $(n=50)$ 25(OH)D düzeyi düşüktür. Cinsiyetler arasında 25(OH)D düzeyleri açısından istatistiksel olarak anlamlı fark mevcuttur $(p=0,031) . \mathrm{Ca}^{+2}, \mathrm{P}, \mathrm{ALP}, \mathrm{PTH}$ düzeyleri arasındaki fark ise anlamlı değildir (Tablo I).

Yaş grupları dikkate alındığında katılımcıların \%70,3'ü ( $n=355$ ) 1-8 yaş grubunda, \%29,3'ü $(n=147)$ 9-17 yaş grubunda yer almaktadır. Birinci grupta ortanca 25(OH)D düzeyi 21,90 $\mathrm{ng} / \mathrm{mL}$ (ÇAU: 15,50 ); 2. grupta $14,47 \mathrm{ng} / \mathrm{mL}$ (ÇAU:14,75) saptanmıştır. PTH ortanca değeri 1. grupta $34,70 \mathrm{pg} / \mathrm{mL}$ (ÇAU: 22,20 ), 2.grupta 44,30 pg/mL'dir (ÇAU:25,60). Yaş grupları arasındaki $25(\mathrm{OH}) \mathrm{D}, \mathrm{PTH}, \mathrm{Ca}^{+2}, \mathrm{P}, \mathrm{ALP}$ ölçümleri açısından istatistiksel fark anlamlıdır. Yaş ile $25(\mathrm{OH}) \mathrm{D}, \mathrm{Ca}^{+2}$, ALP, P arasında negatif, PTH ile pozitif yönde anlamlı korelasyon mevcuttur (Tablo I).

D vitamini değerlendirmesinde güneş ışığı gerekli olduğundan kan örneklerinin alındığı mevsimlere göre de inceleme yapılmıştır. Buna göre $25(\mathrm{OH}) \mathrm{D}$ ortanca değeri yaz mevsiminde 25,35 ng/mL (ÇAU:11,65); kış mevsiminde ise $11,88 \mathrm{ng} / \mathrm{mL}$ (ÇAU:12,37) olarak saptanmıştır. Mevsimler arasında $25(\mathrm{OH})$ D düzeyleri farkının kış mevsiminden kaynaklandığı görülmüştür $(p<0,0001), \quad \mathrm{PTH}, \quad \mathrm{Ca}^{+2}, \mathrm{P}, \quad$ ALP değerleri arasında belirgin fark saptanmamıştır (Tablo 1 ).

\section{Tartışma}

Hem iskelet sisteminin gelişmesi, hem de reseptörlerinin bulunduğu tüm dokularda genetik düzenleyici rol oynayan $D$ vitaminin eksikliği çocukluk çağında sağlıklı büyüme ve gelişme için elzemdir [1]. Bu çalışmada katılımcıların yarısından fazlasında eksiklik veya yetersizlik olması konunun önemli bir halk sağlığı sorunu olduğunu ortaya koymaktadır. Bu durumun
Güneş ışınlarının yetersiz olduğu dönemlerde şiddetlenmesi, ileri yaşlarda ve kız çocuklarında sıklığının artması literatürle uyumlu bulgulardır.

İskelet sistemi üzerindeki etkileri iyi bilindiğinden D vitamini eksikliği "PTH salınımını tetikleyen eşik değer" olarak tanımlanmaktadır. Yaşanılan coğrafi bölgenin ekvatora yakınlığı, yıllık güneşli gün sayısı, solar Zenith açısı gibi yerel özellikler, kemik metabolizmasının yaş ve cinsiyetle değişen aktivitesi ve hızı eşik değer konusunda fikir birliği oluşmasını zorlaştırmaktadır [1]. $25(\mathrm{OH})$ D düzeylerinin ölçülmesindeki teknik zorluklar ve ölçüm yöntemleri arasında oluşan farklılıklar da önemli bir sorundur, likit kromotografi-"tandem mass", "radyoimmünassay," yüksek basınçlı likit kromotografi ve bizim çalışmamızda kullanılan "elektrokemoluminesans" yöntemleri sonuçların genelleştirilmesini zorlaştırmaktadır [16]. Avrupa ve Amerika Birleşik Devletleri'ndeki meslek kuruluşları farklı bildirimlerde bulunmalarına karşın son yıllarda ülkemizde Sağlık Bakanlığımız tarafından da önerilen eşik değer 2015 yılında Endokrin Derneği'nin bildirdiği gibi $12 \mathrm{ng} / \mathrm{ml}$ (30 nmol/l) dir [8-10].

Güneş ışığı etkinliğinin azaldığı mevsimlerde, ilerleyen yaşlarda ve kız çocuklarında eksiklik oranı daha fazladır. D vitamini eksikliği Kuzey Yarımküre'de ılıman iklim kuşağında yer alan ilimiz ve ülkemiz için önemli bir halk sağlığı sorunudur $[5,17]$. İstanbul'da yapılan ve yeterlilik eşik değerinin $30 \mathrm{ng} / \mathrm{ml}$ alındığı çalışmada erken çocuklukta \%40-45 civarında olan D vitamini eksikliği 10 yaşından itibaren \%80-90'lara çıkmaktadır [5]. Ankara çalışmasında ise eksiklik için sınır değer $<20 \mathrm{ng} / \mathrm{ml}$, yetersizlik için $20-30 \mathrm{ng} / \mathrm{ml}$ alınmış ve olguların \%8'inde eksiklik, \%25,5'inde yetersizlik saptanmıştır [17]. Tüm dünyada, özellikle çocuk, kadın ve göçmenleri etkileyen bir durumdur [18]. Bizim çalışmamıza katılan 502 çocuğun \%26,7'sinde 25(OH)D düzeyi düşük; yani "nutrisyonel riketsin önlenmesinde öngörülen eşik değer olan 12 ng/ml" nin altında saptanmıştır. Buna ek olarak \%26,1 $(n=131)$ katılımcıda yetersizlik söz konusudur. PTH'ya göre belirlenen ve riketsi önlemeye dayalı bu değerlerin $D$ vitamininin kemik dokusu dışındaki etkileri konusunda ne kadar doğru bilgi verdiği tartışma konusudur; ayrıca eksiklik durumunda PTH yanıtının oluşması için yaklaşık 40 gün gereklidir [19]. Merkezi sinir sistemi, 


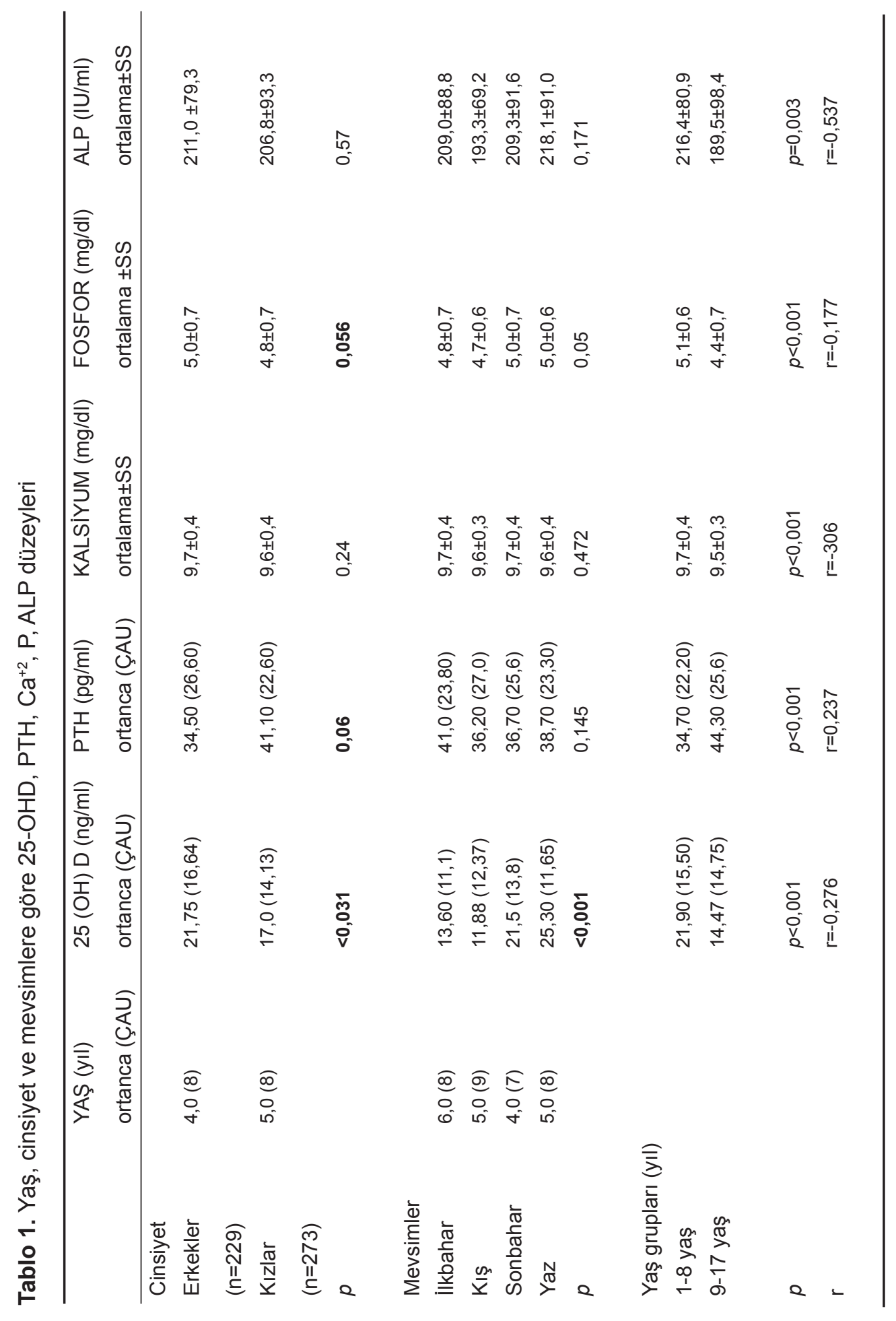


kardiyovasküler sistem, bağışıklık sistemi başta olmak üzere pek çok dokuda düzenleyici rolü vardır. Yapılan çalışmalar D vitamini eksikliğinin patogenezde aktif rol oynamasa bile kronik ve kritik hastalıkların tedavisinde ve akut atakların önlenmesinde yararlı olduğunu, var olan eksiklik düzeltildiğinde asıl hastalığın tedavisine yanıtın arttığını göstermiştir [20, 21]. Amerikan Pediatri Akademisi verilerine göre ise bizim çalışma grubumuzda eksiklik (25 (OH)D<15 ng/dL) oranı \%35,7 $(n=179)$, yetersizlik oranı $(25(\mathrm{OH})$ $\mathrm{D}=15-20 \mathrm{ng} / \mathrm{ml}) \% 17,1(\mathrm{n}=86)$, yeterlilik $(25(\mathrm{OH})$ $\mathrm{D}>20 \mathrm{ng} / \mathrm{dL})$ oranı ise $\% 47,2(\mathrm{n}=237)$ 'dir [8].

D vitamini eksikliğinin yaşla artması, özellikle kız çocuklarında bu durumun anlamlı fark oluşturması bizim çalışmamızın önemli bulgularındandır, literatürle de uyumlu olan bu sonuçların pek çok nedeni olabilir: Bebeklik ve erken çocukluk döneminde hem hekimler, hem de aileler vitamin desteği almaya daha eğilimlidirler. Ülkemizde, 2005 yılından beri doğumdan itibaren yaşamın ikinci yılına kadar tüm bebeklere D vitamini destek programı, ücretsiz olarak aile sağlığı merkezlerinden sağlanmaktadır. Buna göre 1 damlasında 133 Ü kolekalsiferol içeren solüsyonlar günde bir kez 3 damla olarak; yani yaklaşık 400ü/ gün dozunda tüm bebeklere önerilmektedir [6]. Bu yaşlarda giyim özellikleri ve dışarıda geçirilen oyun zamanının fazla olması güneş ışığı maruziyetini de arttırmaktadır. Tersine ilerleyen yaşlarda benimsenen kapalı giyim tarzı, yiyecek seçiminde besin kalitesi düşük gıdalara yönelme, merkezi sınavlar ve ağır ders programları nedeniyle fiziksel aktivite ile dışarıda geçirilen zamanın azalması, güneş koruyucu krem kullanımının yaygınlaşması, ekran maruziyetinin artması sonucu $D$ vitamini üretimi azalmaktadır [22]. Bu durumun önüne geçilmesi için yaşamın ilk bir yılında 400 Ü/gün, daha sonraki yıllarda 600-800 Ü/gün D vitamini ve ortalama $1000 \mathrm{mg} / g u ̈ n$ kalsiyum desteği tüm bireylere önerilmektedir [23]. Gebelere de bakanlık tarafından uygulanmakta olan destek 1200Ü/gün olmak üzere 2011 yılından beri devam etmektedir. Nitekim ülkemizde Gazi Üniversitesi tarafından yürütülen ve D vitamini destek programlarının değerlendirildiği geniş çaplı çalışmanın raporunda 6-17 ay arası çocukların \%73,2'sinde $25(\mathrm{OH}) \mathrm{D}$ düzeyi $15 \mathrm{ng} / \mathrm{ml}$ 'nin üzerinde bulunmuştur [24]. Bazı ülkelerde mama, tahıl, süt ürünleri gibi yiyeceklerin $D$ vitamini ile zenginleştirilmesi söz konusudur, ancak tüketim miktarı ile yakından ilişkili olan bu çözüm destek tedavisi kadar etkin olamamaktadır [25]. Bu çalışmanın en önemli eksik yanlarından biri vitamin kullanımı, diyet özellikleri, yaşam tarzı bilgileri, güneş koruyucu kullanımı, fiziksel aktivite, dışarıda geçirilen zaman gibi bilgileri içermemesidir.

D vitamini, $\mathrm{Ca}^{+2}, \mathrm{P}, \mathrm{ALP}$ ve $\mathrm{PTH}$ arasındaki denge hem kemik döngüsünün, hem de $\mathrm{Ca}^{+2}-\mathrm{P}$ dengesinin belirleyicisidir. PTH ile $25(\mathrm{OH})$ $\mathrm{D}$ arasındaki ters orantı bilinmektedir, ancak PTH'nın hangi kesim noktasında ve kaç günde tetiklendiği coğrafik ve bireysel farklılıklar gösterebilmektedir $[19,26] . \mathrm{Ca}^{+2}$ ve $\mathrm{PTH}$ güvenilir laboratuvar değişkenleri olarak bu dengenin tanımlanmasına yardımcı olur; ancak $P$ ve ALP onlar kadar güvenilir değildir, çevresel koşullardan, özellikle pediatrik kan örneklerinde sık karşılaşılan bir durum olan hemolizden çok etkilenirler [27]. "Yeterli D vitamini düzeyi" ise "PTH eğrisinin plato çizmesini sağlayan eşik değer" olarak tanımlanmaktadır [4]. Bizim çalışmamızda PTH yüksekliği (PTH>65 $\mathrm{pg} / \mathrm{ml}) 50$ hastada (\%10) saptanmıştır ve bunların \%46'sında $(n=23) 25(\mathrm{OH}) \mathrm{D}$ düzeyleri düşüktür, 111 hastada $(\% 82,8) 25(\mathrm{OH})$ D düzeyi düşük olmasına karşın $\mathrm{PTH}$ düzeyleri artmamıştır. Bu durumun kullanılan ölçüm tekniklerinin farklı olmasından veya eksiklik karşısında PTH yanıtının henüz oluşmamış olmasından kaynaklanabileceği düşünülmüştür. Katılımcıların klinik özelliklerinin bilinmiyor olması belirlenen eksiklik eşik değerinin iskelet sistemi dışı etkiler konusunda yorum yapmayı güçleştirmektedir. Bu durum çalışmanın en güçsüz yanlarından biridir. $\mathrm{Bu}$ hastaların sadece 12 tanesinden el bilek grafisi istendiği ve 10 olguya yüksek doz $D$ vitamini ve $\mathrm{Ca}^{+2}$ desteği reçete edildiği görülmüştür. Çalışma grubumuzun D vitamini eksikliği olan olgularının ortalama $p$ değerleri beklenenden yüksek, ALP değerleri ise düşük saptanmıştır, bunun nedenini daha önce de belirtildiği gibi hemolizden kaynaklanabileceği düşünülmüş; ancak teknik olanaksızlıklar nedeniyle hemolitik indeks kayıt altına alınamamıştır. Bu da çalışmanın eksik yanlarından bir tanesidir.

Sonuç olarak, D vitamini pek çok sistemi etkileyen bir hormon olduğundan eksiklik varlığında yerine konması önerilir. Çalışmamızın daha önce belirtilen katılımcılara ait öykü eksikliklerinin yanında sadece hastaneye 
başvuran hastaları ve onlara ait kayıtları geriye doğru bildiren bir rapor olması nedeniyle önemli kısıtlılıkları mevcuttur. Eksiklik saptanan olgularının hastaneye başvuru nedenleri, klinik özellikleri, takipleri belirtilmemiştir. Çalışma grubunun çok sayıda kronik hastalığı olmayan çocuktan oluşması ise en güçlü yanıdır. Sağlıklı çocuklarda bile yaygın olan D vitamini eksikliğinin önlenmesi için tarama yapılmaksızın dozları yaş gruplarına göre belirlenen ve tüm bireyleri kapsayan destek tedavilerinin uygulanmasının, klinik gereklilik durumunda hekim kontrolü altında tarama yapılmasının ve sadece hekim önerisiyle yüksek doz tedavi protokollerinin kullanılmasının gerektiği düşünülmektedir.

Çıkar ilişkisi: Yazarlar çıkar ilişkisi olmadığını beyan eder.

\section{Kaynaklar}

1. Antonucci R, Locci C, Clemente MG, Chicconi E, Antonucci L. Vitamin D deficiency in childhood: old lessons and current challenges. J Pediatr Endocrinol Metab 2018;31:247-260. https://doi.org/10.1515/jpem2017-0391

2. Holick M, Mclaughin JA, Doppelt SH. Science 1981;211:590-593.

3. Bikle DD. Vitamin D: an ancient hormone. Exp Dermatol 2011;20:7-13. https://doi.org/10.1111/j.16000625.2010.01202.x

4. Atapattu N, Shaw N, Högler W. Relationship between serum 25- hydroxyvitamin $\mathrm{D}$ and parathyroid hormone in the search for a biochemical definition of vitamin $D$ deficiency in children. Pediatr Res 2013;74:552-556. https://doi.org/10.1038/pr.2013.139

5. Şahin ÖN, Serdar M, Serteser M, Ünsal İ, Özpınar A. Vitamin $D$ levels and parathyroid hormone variations of children living in a subtropical climate: a data mining study. Ital J Pediatr 2018;44:40. https://doi.org/10.1186/ s13052-018-0479-8

6. Hatun S, Bereket A, Ozkan B, Coşkun T, Köse R, Çalıkoğlu AS. Free vitamin D supplementation for every infant in Turkey. Arch Dis Child 2007;92:373-374. https://doi.org/10.1136/adc.2006.113829

7. Reeve LE, Chesney RW, DeLuca HF. Vitamin D of human milk: identification of biologically active form. Am J Clin Nutr 1982;36:122-126. https://doi.org/10.1093/ ajcn/36.1.122

8. Misra M, Pacaud D, Petryk A, Collett Solberg PF, Kappy M. Drug and Therapeutics Committee of the Lawson Wilkins Pediatric Endocrine Society. Vitamin D deficiency in children and its management: review of current knowledge and recommendations. Pediatrics 2008;122:398-417. https://doi.org/10.1542/peds.20071894
9. Munns CF, Shaw N, Kiely M, et al. Global consensus recommendations on prevention and management of nutritional rickets. J Clin Endocrinol Metab 2016;101:394-415. https://doi.org/10.1210/jc.20152175

10. Çocuklarda D vitamini kullanımı önergesi. T.C. Sağıı Bakanlığı, Halk Sağlığı Müdürlüğü. Erişim adresi: https://hsgm.saglik.gov.tr/tr/cocukergen-yayınlar. Erişim tarihi 10 Ekim 2019

11. Kang JI, Lee YS, Han YJ, Kong KA, Kim HS. The serum level of 25-hydroxyvitamin $D$ for maximal suppression of parathyroid hormone in children: the relationship between 25- hydroxyvitamin $D$ and parathyroid hormone. Korean J Pediatr 2017;60:45-49. https://doi. org/10.3345/kjp.2017.60.2.45

12. Hill KM, McCabe GP, McCabe LD, Gordon CM, Abrams SA, Weawer CM. An inflection point of serum 25-hydroxyvitamin $D$ for maximal suppression of parathyroid hormone is not evident from multisite pooled data in children and adolescents. J Nutr 2010;140:1983-1988 https://doi.org/10.3945/ jn.110.124966.

13. T.C. Meteoroloji Genel Müdürlüğü. Hava durumu raporları Erişim adresi: https://www.mgm. gov.tr/veridegerlendirme/il-ve-ilceler-istatistik. aspx?m=AMASYA. Erişim tarihi 23 Eylül 2019

14. T.C. Amasya Valiliği. Coğrafi konum. Erişim adresi: http://www.amasya.gov.tr/cografi-konum. Erişim tarihi 22 Eylül 2019

15. Tarhan S, Sarı A. Model selection for global and diffuse radiation over the Central Black Sea (CBS) region of Turkey. Energy Conversion and Management 2005;46:605-613.

16. Janssen MJ, Wielders JP, Bekker CC, et al. Multicenter comparison study of current methods to measure 25-hydroxyvitamin D in serum. Steroids 2012;77:13661372. https://doi.org/10.1016/j.steroids.2012.07.013

17. Akman $A O$, Tümer $L$, Hasanoğlu $A$, İlhan $M$, Çaycı $B$. Frequency of vitamin $D$ insufficiency in healthy children between 1 and 16 years of age in Turkey. Pediatr Int 2011;53:968-973. https://doi.org/10.1111/j.1442200X.2011.03486.X

18. Lips P. Vitamin D status and nutrition in Europe and Asia. J Steroid Biochem Mol Biol 20017;103:620-625. https://doi.org/10.1016/j.jsbmb.2006.12.076

19. Kroll $\mathrm{MH}, \mathrm{Bi} \mathrm{C}$, Garber CC, et al. Temporal relationship between vitamin $\mathrm{D}$ status and parathyroid hormone in the United States. PLoS One 2015;10:e0118108. https://doi.org/10.1371/journal.pone.0118108

20. Holick MF. The vitamin D deficiency pandemic and consequences for nonskeletal health: mechanisms of action. Mol Aspects Med 2008;29:361-368. https://doi. org/10.1016/j.mam.2008.08.008 
21. Sankar J, Ismail J, Das R, Dev N, Chitkara A, Sankar MJ. Effect of severe vitamin D deficiency at admission on shock reversal in children with septic shock: a prospective observational study. J Intensive Care Med 2019;34:397-403. https://doi. org/10.1177/0885066617699802

22. Seo JH, Chung HJ, Kim HJ, et al. Increasing vitamin D deficiency in children from 1995 to 2011. Turk J Pediatr 2016;58:616-622. https://doi.org/10.24953/ turkjped.2016.06.007

23. Ross AC, Taylor CL, Yaktine AL, Del Valle HB. Dietary reference intakes for calcium and vitamin $\mathrm{D}$. Washington, The National Academies Press 2011. https://doi.org/10.17226/13050

24. Gazi Üniversitesi Tıp Fakültesi. Türkiye'de 6-17 Aylık Çocuklarda ve Annelerinde Hemoglobin Ferritin D -Vitamini Düzeyi ve Demir Eksikliği Anemisi Durum Belirleme Yürütülen Programların Değerlendirilmesi Araştırması. Erişim adresi: https://hsgm.saglik.gov.tr/ depo/birimler/cocuk_ergen_db/dokumanlar/yayinlar/ Kitaplar/Arastirma_Raporu-16x24.pdf. Erişim tarihi 21 Temmuz 2020

25. Saggese G, Vierucci F, Boot AM, et al. Vitamin D in childhood and adolescence: an expert position statement. Eur J Pediatr 2015;174:565-576. https://doi. org/10.1007/s00431-015-2524-6

26. Steingrimsdottir L, Gunnarsson O, Indridason OS, Franzson L, Sigurdsson G. Relationship between serum parathyroid hormone levels, vitamin D sufficiency, and calcium intake. JAMA 2005;294:2336-2341. https://doi. org/10.1001/jama.294.18.2336

27. Holick MF. Environmental factors that influence the cutaneous production of vitamin D. Am J Clin Nutr 1995;61:638-645. https://doi.org/10.1093/ ajcn/61.3.638S

Etik kurul onayı: Amasya Üniversitesi Girişimsel Olmayan Klinik Araştırmalar Etik Kurulu'ndan alınmıştır (evrak tarih ve sayısı: 27/02/2020-E.5675).

\section{Yazarların makaleye olan katkısı}

Çalışmanın konsepti ve dizaynı: GC, ZHD

Verilerin toplanması ve işlenmesi: ZHD

Verilerin analizi ve yorumlanması: GC, ZHD

Literatür araştırması: GC, ZHD

Makalenin yazımı: GC

Kritik gözden geçirme: GC, ZHD

Yayınlanacak versiyonun nihai onayı: GC, ZHD 